\title{
ANALISIS PENGARUH PERUBAHAN IKLIM DAN SANITASI LINGKUNGAN TERHADAP PENYAKIT DEMAM BERDARAH DENGUE
}

\author{
Fajar Mauladi $^{1)}$ Dian Rahayu Jati ${ }^{1)}$ Agus Fitriangga ${ }^{1)}$ \\ 1)Program Studi Teknik Lingkungan Jurusan Teknik Sipil Fakultas Teknik Universitas Tanjungpura, Pontianak \\ Email : fajar.mauladi55@gmail.com
}

\begin{abstract}
ABSTRAK
Sektor kesehatan merupakan salah satu sektor yang rentan terhadap pengaruh perubahan iklim, terutama pengaruhnya terhadap penyakit menular vektor seperti demam berdarah. Kondisi sanitasi lingkungan yang buruk juga mempengaruhi penyebaran penyakit demam berdarah di Kalimantan Barat, khususnya di kota Pontianak. Tujuan penelitian ini adalah untuk mengukur hubungan antara faktor iklim dan sanitasi lingkungan di kota Pontianak dan pengaruhnya terhadap jumlah penderita demam berdarah. Metode penelitian yang dilakukan adalah dengan melakukan survey lapangan dan metode korelasi bivariat untuk melihat terjadi hubungan antara beberapa variabel data. Data yang diperlukan antara lain penjabaran kuesioner di 6 kecamatan kota Pontianak untuk mengetahui kondisi sanitasi lingkungan, data pengaruh iklim yang di dapat dari BMKG stasiun supadio kota Pontianak, dan data penderita demam berdarah yang di dapat dari Dinas Kesehatan kota Pontianak. Hasil penelitian menunjukan tidak ada hubungan yang kuat antara faktor iklim, yaitu curah hujan dan suhu terhadap penderita demam berdarah pada tahun 2008-2012 dengan nilai korelasi ( $r$ ) CH 0,070 dan suhu 0,232. Sementara dari hasil kuesioner di dapatkan bahwa hubungan antara pengetahuan dan tindakan masyarakat bernilai lemah ( $r$ ) 0,022 .
\end{abstract}

Kata kunci: Iklim, Sanitasi Lingkungan, Demam Berdarah

ABSTRACT

Health sector is one of sector that vulnerable to climate change effects, particularly its effect on infectious diseases vector such as dengue fever. Poor environmental sanitation also affects the spread of dengue fever in West Kalimantan, especially in Pontianak. The purpose of this study was to measure the correlation between climatic and environmental sanitation factors in Pontianak with the number of dengue fever patients. This research use field surveys and bivariate correlation method to see the correlation between several data variables. The data required is the elaboration of questionnaire in 6 districts of Pontianak to determine the environmental sanitation, climatic influences data obtained from BMKG station Supadio in Pontianak, and dengue fever data obtained from the Health Department of Pontianak. The results showed there was no strong correlation between climate factors, namely precipitation and temperature on dengue fever in 2008-2012 with the correlation value (r) 0.070 for precipitation and 0.232 for temperature. While the questionnaire results showed that the correlation between knowledge and public action is worth a weak (r) 0.022 .

Keywords: Climate, Environmental Sanitation, Dengue Fever 


\section{Pendahuluan}

Iklim kini sulit diprediksi, hal ini terjadi karena efek dari pemanasan global. Indonesia merupakan salah satu negara yang terkena akibat dari perubahan iklim. Perubahan iklim di Indonesia berimbas kepada berbagai masalah beberapa diantaranya adalah meningkatnya bencana alam, meningkatnya frekuensi penyakit tropis salah satunya yaitu demam berdarah dengue. Perubahan iklim dapat memperpanjang masa penularan penyakit yang ditularkan melalui vector dan mengubah luas geografisnya, dengan kemungkinan menyebar ke daerah yang kekebalan populasinya rendah atau dengan infrastruktur kesehatan masyarakat yang kurang. Selain perubahan iklim faktor resiko yang mempengaruhi penularan demam berdarah dengue adalah faktor lingkungan, urbanisasi, mobilitas penduduk, kepadatan penduduk dan transportasi.

Sektor kesehatan merupakan salah satu sektor yang rentan terhadap dampak perubahan iklim, sehingga antisipasi perubahan iklim terhadap sektor kesehatan di Indonesia dan lingkungannya merupakan hal yang sangat penting. Kondisi lingkungan sangat berpengaruh terhadap status kesehatan, jika kondisi lingkungan tidak baik maka dapat menimbulkan berbagai masalah kesehatan pada masyarakat. Sanitasi lingkungan yang buruk dapat menyebabkan penularan penyakit terus menyebar. Beberapa penyakit menular diantaranya penyakit malaria, TBC, filariasis, demam berdarah dengue, kolera, diare dan sebagainya. Penyakit demam berdarah disebut juga Dengue Haemorrhagic Fever (DHF) karena disertai gejala demam dan pendarahan, sedangkan penyebabnya adalah virus yang tergolong virus dengue.

Kondisi sanitasi lingkungan di beberapa rumah di wilayah Kota Pontianak cukup baik, namun masyarakat kurang waspada terhadap tempat perindukan nyamuk seperti adanya tempat penampungan air bersih yang terbuka, bak mandi yang jarang di bersihkan dan pengolahan sampah padat yang masih kurang baik, serta masih kurangnya kepemilikan saluran pembuangan air limbah, sehingga menjadi salah satu faktor risiko terjadinya penyakit demam berdarah dengue (DBD). Oleh karena itu, penelitian ini dilakukan untuk mengetahui bagaimana hubungan perubahan iklim dan sanitasi lingkungan terhadap penyakit demam berdarah di Kota Pontianak.

\section{Metodologi Penelitian}

a. WAKTU DAN LOKASI

Lokasi studi di Kota Pontianak di enam Kecamatan sebagai aspek penelitian. Kecamatan Pontianak Utara, Kecamatan Pontianak Timur, Kecamatan Pontianak Tenggara, Kecamatan Pontianak Selatan, Kecamatan Pontianak Barat dan Kecamatan Pontianak Kota. Penelitian ini akan dilaksanakan selama 1 bulan yang akan dimulai pada bulan Desember 2014.

\section{b. PENGUMPULAN DATA}

Data yang diperlukan pada penelitian ini yaitu data primer dan data sekunder. Untuk data primer yaitu kondisi sanitasi lingkungan di tiap kecamatan. Sedangkan data sekunder yaitu jumlah penderita penyakit demam berdarah dalam kurun waktu enam tahun dari tahun 2008 sampai 2012 di Dinas Kesehatan Kota Pontianak. Data suhu, curah hujan dan kelembaban perbulan dalam kurun waktu 
enam tahun dari tahun 2008 sampai 2012 di Badan Meteorologi Klimatologi dan Geofisika Kota Pontianak.

\section{c. RANCANGAN PENELITIAN}

Penelitian ini bersifat statistik deskriptif dan merupakan studi kuantitatif dengan pendekatan cross sectional yang mana untuk membuat gambaran atau deskripsi mengenai suatu keadaan secara objektif, dan untuk mengetahui hubungan suatu sebab dan akibat dengan cara mengkorelasikan hubungan tersebut.

Data kuesioner digunakan untuk melihat hubungan pengetahuan dan tindakan responden denga mengkorelasikan kedua hal tersebut, serta untuk melihat kondisi sanitasi masyarakat setempat dikaitkan dengan jumlah penderita penyakit demam berdarah dengue (DBD).

- Tahap Pra-Penelitian

Tahap pra-penelitian adalah kegiatan yang dilakukan sebelum melakukan penelitian. Adapun kegiatan pra-penelitian adalah :

1. Pengurusan perijinan penelitian kepada Dinkes Kota Pontianak dan BMKG Kota Pontianak.

2. Mempersiapkan alat tulis untuk pengambilan data.

Pengambilan data di Dinkes Kota Pontianak dan BMKG Kota Pontianak. Untuk Dinas Kesehatan Kota diperlukan data jumlah penderita penyakit demam berdarah sedangkan di BMKG Kota Pontianak diperlukan data curah hujan, suhu dan kelembaban. Di perlukan data enam tahun pada bulan Januari 2008 sampai bulan Desember 2012.

- Tahap Penelitian

Tahap penelitian adalah kegiatan yang dilakukan saat penelitian. Adapun kegiatan pada tahap penelitian adalah :

1. Mengunjungi ke enam kecamatan Kota Pontianak untuk melihat kondisi sanitasi lingkungan yang ada. Di uji dengan 60 sampel.

2. Memberikan kuisioner kepada masyarakat yang dijadikan sampel.

3. Mendokumentasikan tempat sampel penelitian.

4. Meneliti kembali setiap data yang didapatkan meliputi kelengkapan dan kesalahan data.

5. Melakukan pengelompokan data sedemikian rupa agar dapat dengan mudah disusun, dan ditata untuk disajikan dan dianalisis.

6. Menggunakan 2 metode, yaitu univariat dan bivariat. Univariat yaitu cara penyajian data dengan berbentuk tabel dan diagram. Sedangkan bivariat yaitu uji statistik dengan mengkorelasikan kedua variable data.

7. Melakukan olah data dengan program SPSS dengan korelasi bivariate dan menggunakan grafik scatter plot.

- $\quad$ Analisa Data

Pada penelitian ini menggunakan metode deskriptif, menggambarkan suatu objek pada saat sekarang berdasarkan fakta-fakta yang ada, kemudian dianalisis. 


\section{Hasil dan Pembahasan}

a. Analisa Hubungan Curah Hujan Terhadap Jumlah Penderita Demam Berdarah Tahun 2008-2012

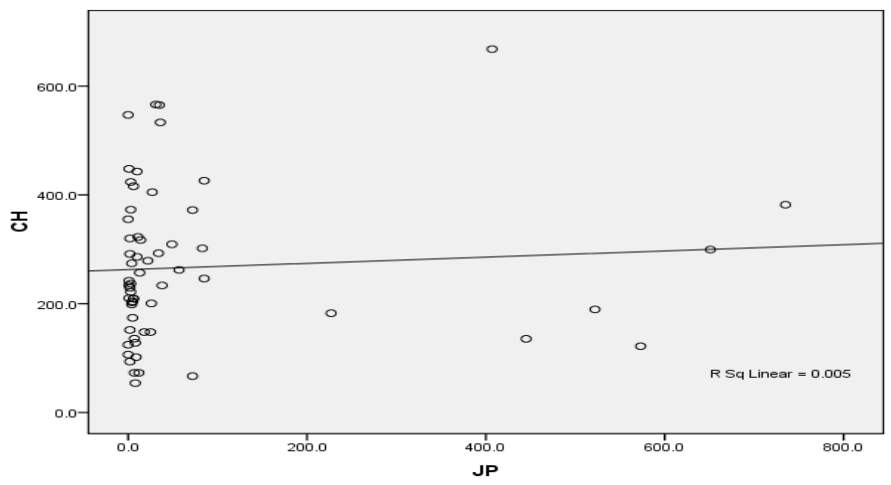

Gambar 1. Hubungan Curah Hujan Terhadap Jumlah Penderita DBD Tahun 2008-2012

Dari gambar 1 menunjukan bahwa data menyebar di garis kurva $Y$ dengan nilai $r$ linear 0,005 . Nilai ini menunjukan hubungan antara variable curah hujan dan jumlah penderita DBD memiliki nilai positif karena garis linear berada naik ke kanan dan memiliki hubungan yang sangat lemah, yang artinya kenaikan curah hujan tidak memiliki pengaruh yang besar terhadap kenaikan jumlah penderita.

b. Analisa Hubungan Suhu Terhadap Jumlah Penderita Demam Berdarah Tahun 2008-2012

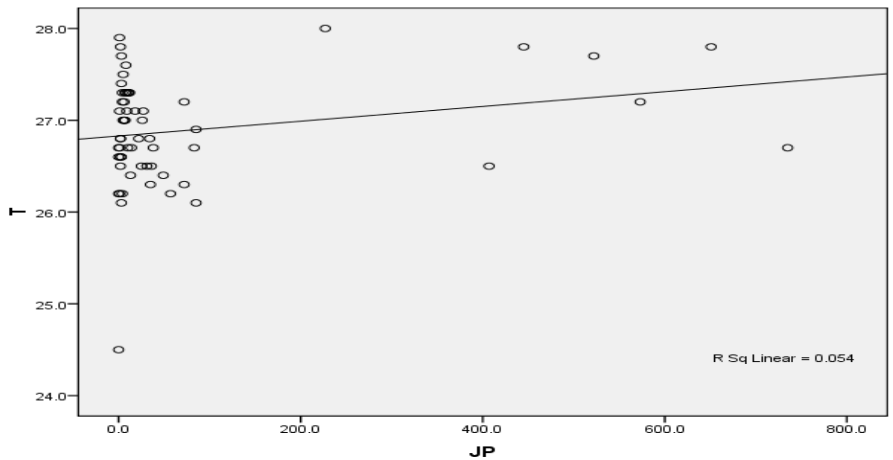

Gambar 2. Hubungan Suhu Terhadap Jumlah Penderita DBD Tahun 2008-2012

Dari gambar 2 diatas menunjukan bahwa data lebih banyak menyebar di kurva $Y$ di garis linear dengan nilai $r$ linear 0,054 . Nilai ini menunjukan hubungan antara variable suhu dan jumlah penderita DBD memiliki nilai positif karena garis linear berada naik ke kanan dan memiliki hubungan yang sangat lemah, yang artinya kenaikan curah hujan tidak memiliki pengaruh yang besar terhadap kenaikan jumlah penderita. 
c. Analisa Hubungan Kelembaban Terhadap Jumlah Penderita Demam Berdarah Tahun 2008-2012

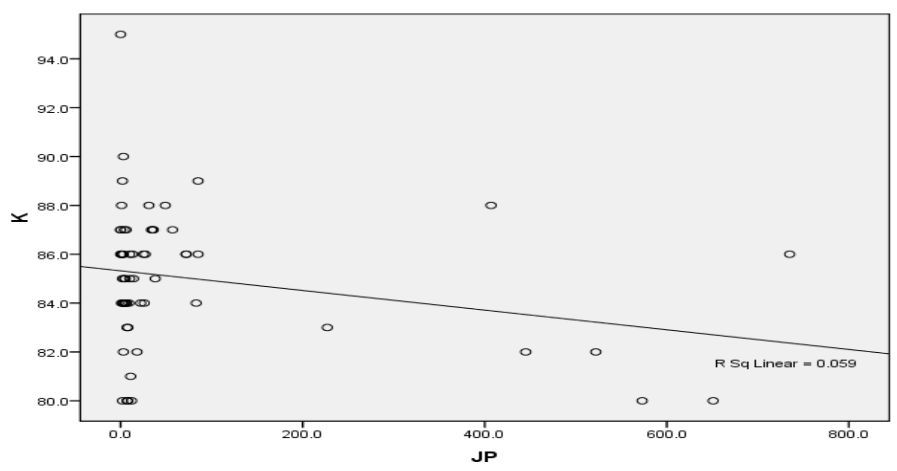

Gambar 3. Hubungan Suhu Terhadap Jumlah Penderita DBD Tahun 2008-2012

Dari gambar 4.3 diatas menunjukan bahwa data lebih banyak menyebar di kurva $Y$ garis linear dengan nilai $r$ linear 0,059. Nilai ini menunjukan hubungan antara variable kelembaban dan jumlah penderita DBD memiliki nilai negatif karena garis linear berada naik ke kiri dan memiliki hubungan yang sangat lemah, yang artinya kenaikan kelembaban tidak memiliki pengaruh yang besar terhadap penurunan jumlah penderita.

d. Analisis Pengetahuan dan Sikap Tindakan Masyarakat Mengenai Penyakit Demam Berdarah Dengue

> Analisis Pengetahuan Masyarakat Mengenai Penyakit Demam Berdarah Dengue

Table 1 Jawaban Responden Terhadap Pertanyaan Kuesioner yang Terkait Pengetahuan Demam Berdarah Dengue

\begin{tabular}{|l|l|l|}
\hline No & \multicolumn{1}{|c|}{ Pernyataan } & $\begin{array}{l}\text { Jumlah } \\
\text { responden }\end{array}$ \\
\hline 1 & $\begin{array}{l}\text { Bak penampung air yang dipakai setiap hari, perlu untuk } \\
\text { ditutup }\end{array}$ & $98,3 \%$ \\
\hline 2 & $\begin{array}{l}\text { Tempat berkembangbiaknya nyamuk DBD berada di } \\
\text { tempat yang kotor }\end{array}$ & $63,3 \%$ \\
\hline 3 & $\begin{array}{l}\text { 3M merupakan solusi yang tepat untuk pencegahan } \\
\text { penyakit DBD }\end{array}$ & $95 \%$ \\
\hline 4 & $\begin{array}{l}\text { Fogging dan bubuk abate salah satu cara mencegah } \\
\text { perkembangbiakan nyamuk DBD }\end{array}$ & $91,6 \%$ \\
\hline
\end{tabular}




\begin{tabular}{|l|l|l|}
\hline 5 & $\begin{array}{l}\text { Tempat penampungan air seperti bak mandi, tempayan } \\
\text { perlu dikuras setiap minggu }\end{array}$ & $91,6 \%$ \\
\hline 6 & $\begin{array}{l}\text { Perubahan iklim/cuaca sangat berpengaruh terhadap } \\
\text { jumlah penderita penyakit DBD }\end{array}$ & $81,6 \%$ \\
\hline 7 & $\begin{array}{l}\text { Plastik bekas di jalan sekitar rumah anda dibiarkan tidak } \\
\text { mempengaruhi timbulnya penyakit DBD }\end{array}$ & $21,6 \%$ \\
\hline 8 & $\begin{array}{l}\text { Pembersihan lingkungan sekitar dapat mengurangi } \\
\text { pencegahan terjadinya DBD }\end{array}$ & $96,6 \%$ \\
\hline
\end{tabular}

Berdasarkan Tabel 1 diatas dapat dilihat pengetahuan responden mengenai penyakit demam berdarah sebesar $80 \%$ ( untuk beberapa pernyataan seperti bak penampung air yang ditutup mayoritas $98,3 \%$, melakukan $3 \mathrm{M} 95 \%$, fogging dan abate $91,6 \%$, tempat penampung air dikuras setiap minggu $91,6 \%$, perubahan iklim mempengaruhu jumlah penderita DBD $81,6 \%$ dan pembersihan lingkungan 96,6\%). Secara umum masyarakat tahu akan cara pencegahan dalam mengatasi pencegahan penyakit DBD.

\section{Analisis Tindakan Masyarakat Mengenai Penyakit Demam Berdarah Dengue}

Dari hasil kuesioner yang didapatkan maka dapat diketahui berapa jumlah responden yang benar-benar memahami (sangat setuju dan setuju) dalam hal tindakan menangani permasalahan dalam hal penyakit demam berdarah dengue. Berikut pernyataan beserta persentase responden yang dapatkan.

Tabel 2 Jawaban Responden terhadap Penyataan Kuesioner yang Terkait Tindakan Pencegahan Demam Berdarah Dengue

\begin{tabular}{|l|l|l|}
\hline No & \multicolumn{1}{|c|}{ Pernyataan } & $\begin{array}{l}\text { Jumlah } \\
\text { Responden }\end{array}$ \\
\hline 1 & Menutup seluruh bak penampung air dirumah & $65 \%$ \\
\hline 2 & $\begin{array}{l}\text { Membersihkan tempat-tempat yang kotor yang } \\
\text { berpotensi tempat berkembangbiaknya nyamuk } \\
\text { DBD }\end{array}$ & $66,7 \%$ \\
\hline 3 & Melakukan 3M & $46,7 \%$ \\
\hline 4 & Melakukan fogging dan bubuk abate & $15 \%$ \\
\hline 5 & Menguras bak mandi dan tempayan setiap minggu & $61,7 \%$ \\
\hline 6 & $\begin{array}{l}\text { Melakukan pengumpulan dan pemusnahan } \\
\text { sampah plastic di perumahan }\end{array}$ & $48,3 \%$ \\
\hline
\end{tabular}




\begin{tabular}{|l|l|l|}
\hline 7 & $\begin{array}{l}\text { Melakukan pembersihan lingkungan bersama } \\
\text { masyarakat dengan mengadakan gotong royong }\end{array}$ & $45 \%$ \\
\hline
\end{tabular}

Berdasarkan Tabel 2 dapat dilihat tindakan responden yang melakukan tindakan pencegahan DBD sebesar 60\% ( untuk beberapa pernyataan seperti menutup bak penampung air $65 \%$, membersihkan tempat kotor yang berpotensi berkembang biaknya nyamuk $66,7 \%$ dan menguras bak mandi dan tempayan setiap minggu $61,7 \%$ ).

\section{Persentase Tindakan Masyarakat Terkait Sanitasi Lingkungan Dalam} Rangka Mengurangi Jumlah Penderita DBD

- Menutup Seluruh Bak Penampung Air di Rumah

Dari hasil jawaban 60 kuesioner responden yang tersebar kepada masyarakat hanya 38 orang yang melakukan upaya menutup bak penampung air untuk mengatasi penurunan jumlah penderita DBD di enam Kecamatan Kota Pontianak dengan rincian sebagai berikut berikut:

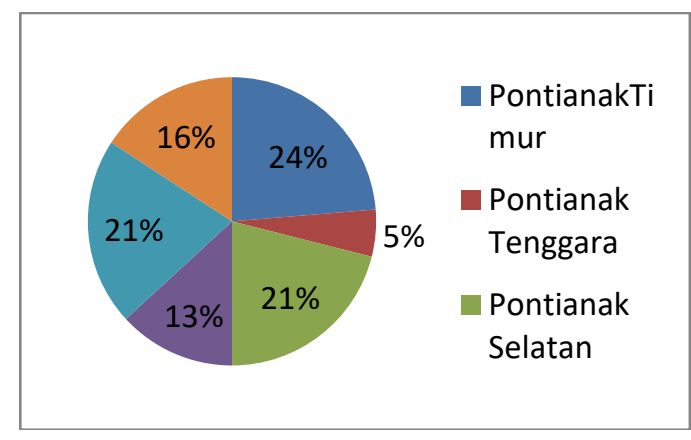

Gambar 4 Persentase Responden dalam Menutup Bak Penampung Air

\section{- Melakukan 3M}

Dari hasil jawaban 60 kuesioner responden yang tersebar hanya 28 orang yang melakukan upaya menutup bak penampung air untuk mengatasi penurunan jumlah penderita DBD dengan rincian sebagai berikut berikut ini.

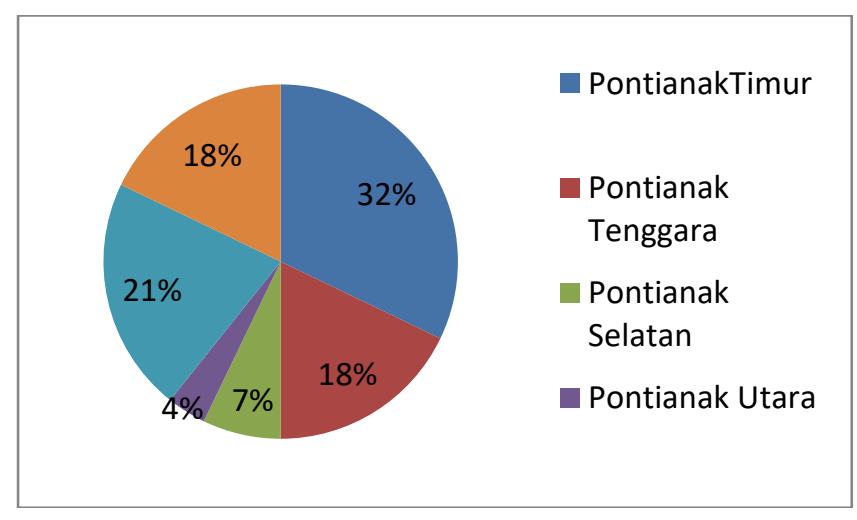

Gambar 5 Persentase Responden dalam Melakukan 3M 
- Melakukan Pembersihan Lingkungan Bersama Masyarakat Dengan Mengadakan Gotong-royong

Dari hasil jawaban 60 kuesioner yang dibagikan kepada masyarakat hanya 27 orang yang melakukan pembersihan lingkungan bersama masyarakat dengan mengadakan gotong royong untuk mengatasi penurunan jumlah penderita DBD di enam kecamatan Kota Pontianak dengan rincian sebagai berikut berikut.

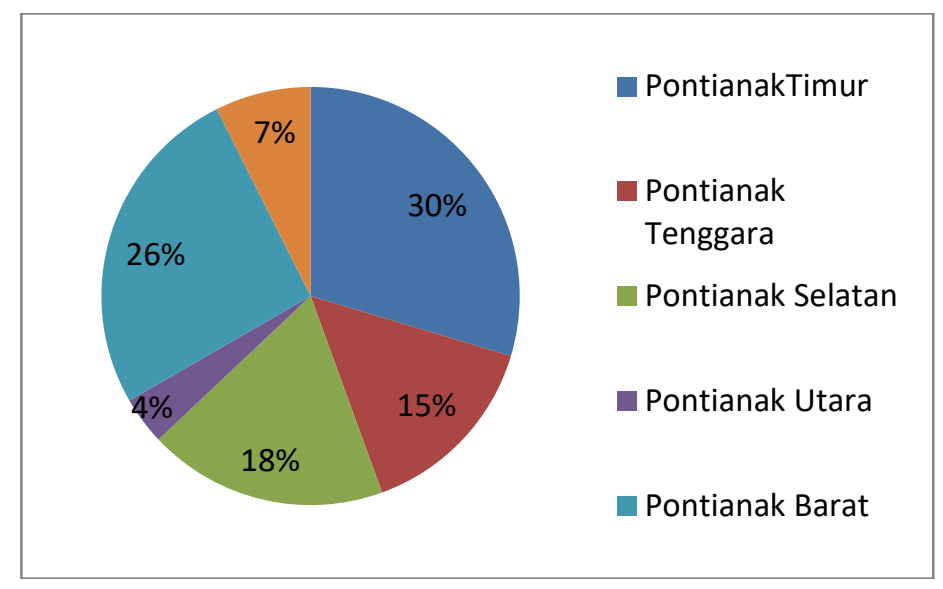

Hubungan Antara Pengetahuan dan Tindakan Responden Terkait Sanitasi Lingkungan Dalam Mengatasi Pengurangan Jumlah Penderita DBD.

Dari hasil analisa pengetahuan dan tindakan responden mengenai sanitasi lingkungan untuk mengatai pengurangan jumlah penderita DBD maka dapat dikorelasikan kedua variable tersebut dengan menggunakan aplikasi SPSS. Tujuan korelasi adalah untuk mengetahui ada atau tidaknya ikatan yang kuat atau lemah antara variable yang akan dikorelasikan. Berikut hasil yang didapatkan antara pengetahuan dan tindakan responden.

Table 3 Korelasi bivariate dengan menggunakan uji Spearmen antara Tingkat Pengetahuan terhadap Tindakan Responden

Correlations

\begin{tabular}{|ll|l|l|}
\hline & & Pengetahuan & sikap \\
\hline Spearman's rho pengetahuan & Correlation & 1.000 & .022 \\
& Coefficient & & \\
& Sig. (2-tailed) &. & .870 \\
& $\mathrm{~N}$ & 60 & 60 \\
\cline { 2 - 4 } & Correlation & .022 & 1.000 \\
& Coefficient & & \\
& Sig. (2-tailed) & .870 &.
\end{tabular}




\section{Correlations}

\begin{tabular}{|ll|l|l|}
\hline & & Pengetahuan & sikap \\
\hline Spearman's rho pengetahuan & Correlation & 1.000 & .022 \\
& Coefficient & & \\
& Sig. (2-tailed) &. & .870 \\
& $\mathrm{~N}$ & 60 & 60 \\
& Correlation & .022 & 1.000 \\
& Coefficient & & \\
& Sig. (2-tailed) & .870 &. \\
& $\mathrm{~N}$ & 60 & 60 \\
\hline
\end{tabular}

Dari table 3 korelasi menggunakan SPSS menunjukkan bahwa hubungan antara pengetahuan dan tindakan lemah, yaitu 0,022 sehingga pengetahuan yang dimiliki responden terkait demam berdarah dan penanggulangannya tidak berpengaruh terhadap tindakan yang responden lakukan.

\section{Kesimpulan}

\section{$>$ Kesimpulan}

1. Variabel iklim tahun 2008-2012 tidak memiliki pengaruh yang kuat terhadap tingkat penderita demam berdarah di tahun tersebut.

2. Tidak ditemukan hubungan antara tindakan sanitasi lingkungan dengan jumlah penderita demam berdarah di enam Kecamatan Kota Pontianak.

3. Berdasarkan hasil kuesioner tidak ada hubungan antara tingkat pengetahuan dan tindakan responden dalam mengurangi penyakit demam berdarah

\section{UCAPAN TERIMAKASIH}

Dengan selesainya perancangan ini saya mengucapkan terima kasih yang sebesarbesarnya kepada Allah Swt, kedua orang tua, kedua dosen pembimbing yaitu Ibu Dian Rahayu Jati,S.T,M.Si dan Bapak Agus Fitriangga,S.KM,M.KM serta kepada teman-teman Teknik Lingkungan 2008 dan semua orang yang telah berperan dalam membantu penelitian yang tidak dapat di ucapkan satu persatu. Harapan saya penelitian ini dapat bermanfaat bagi semua dan dapat dipergunakan sebagaimana mestinya.

\section{DAFTAR PUSTAKA}

Departemen Kesehatan RI, Tata Laksana DBD, Jakarta : Dep Kes RI (2005).

Departemen Kesehatan Republik Indonesia, 2010, Penemuan dan Tatalaksana

Penderita Demam Berdarah Dengu, Jakarta: Dirjen P2L.

Judarwanto W. 2007. Profil Nyamuk Aedes Aegypti dan Pembasminya, Jakarta.

Kusnoputranto, Haryoto, 1986. Kesehatan Lingkungan. Depdikbud, Fakultas Kesehatan Masyarakat Universitas Indonesia, Jakarta.

Regariana, Cut Meurah, 2004, Atmosfer (Cuaca dan Iklim), Solo: Tiga Serangkai. 
S. E, Yanti, 2004, "Hubungan Faktor-Faktor Iklim dengan Kasus Demam Berdarah Dengue di Kotamadya Jakarta Timur Tahun 2000-2004," Skripsi Fakultas Kesehatan Masyarakat, Universitas Indonesia.

United Nations Development Programme (UNDP) - Indonesia. 2007. The Other Half of Climate Change: Why Indonesia Must Adapt to Protect Its Poorest People. 20pp. Jakarta: UNDP 